\title{
An Appraisal of Sciences and Mathematics Dyslexia and Dyscalculia Syndrome among Secondary Schools Students
}

\author{
OGINNI Omoniyi Israel", OLUGBUYI Peter Olubunmi \\ Department of Curriculum Studies, Faculty of Education, Ekiti State University, Ado-Ekiti, Nigeria \\ *Corresponding author: omoniyioginni@yahoo.com
}

Received July 11, 2013; Revised March 06, 2014; Accepted April 02, 2014

\begin{abstract}
This study investigated the impact of student's dyscalculia and dyslexia on the teaching and learning of science and mathematics among secondary school students. A descriptive research of survey was adopted for the study. The instrument used to collect data was a structured questionnaire (SQ) designed to elicit response from 200 students that were selected randomly from schools. Data collected were analysed using chi-square. The findings revealed that teachers' students' relationship has a significant effects on dyslexia and dyscalculia among secondary school students. Based on the findings, it was recommended that, teachers should discover the best method that will bring the best performance out of their students. However, continuous assessment and individual differences in learners should be prioritized.
\end{abstract}

Keywords: mathematics, dyscalculia dyslexia anxiety, situational interest

Cite This Article: OGINNI Omoniyi Israel, and OLUGBUYI Peter Olubunmi, "An Appraisal of Sciences and Mathematics Dyslexia and Dyscalculia Syndrome among Secondary Schools Students.” American Journal of Educational Research, vol. 2, no. 4 (2014): 219-224. doi: 10.12691/education-2-4-7.

\section{Introduction}

Dyslexia is a learning disability that affects learner's ability to read and to comprehend mathematics language. This also affects other aspects of student's lives, including their scientific and mathematical abilities. Hence, dyscalculia is an impair ability to learn basic mathematics. It is one of the most crucial problems of learning sciences and mathematics in our secondary schools. In other words, dyslexia and dyscalculia are the prevalent emotional, psychological, physiological and sociological problems associated with sciences and mathematics learning. Baloglu and kocak (2006) expressed that approximately $60 \%$ of dyslexics have problems with mathematics. Often, this is mistaken as another learning difficulty called dyscalculia.

Dyscalculia is the manifestation of vague and unpleasant emotion experienced in a learner which interferes with the manipulation of numbers and solving of sciences and mathematics problems. Many students who suffer from dyscalculia have little confidence in their ability to study mathematics. Dyscalculia is quite rare and individuals diagnosed as possessing this disorder are often actually dyslexic. There are treatments and therapies available to dyscalculia individuals seeking to improve their mathematical skills. Oginni and Owolabi (2013) maintained that mathematics language is the collection of signs or symbols, abbreviations, axioms, lemma, methods, formulae, and units that are necessary in sciences and mathematics teaching and learning. Specific vocabulary that refers to quantities and spatial placement tend to create problems for dyslexic students. These include words and phrases such as before, after, more than, less than, and between. It is difficult for dyslexic students to understand the meaning of such words in relation to sciences and mathematics.

Dyslexia is most prevalent among secondary school students. Studies by Sukri et al (1996) and Jasmani et al (2005) found that majority of students have moderate levels of dyslexia when it comes to learning of non science subjects. Anxiety and unstable innate tendencies has become a serious concern in explaining dyslexia and dyscalculia issue. Evidence of students' poor attitude and high levels of dyslexia and dyscalculia towards sciences and mathematics is highly reflected in their performance in recent times. Poor grades of result in mathematics especially in the "West African Examination Council (WAEC), "National Examination Council” (NECO) and declining scores in "Unified Tertiary Matriculation Examination (UTME) call for concern among scholars. National Bureau of Statistics, (2007) attributed this to several factors among which dyslexia has taken a centre stage.

Dyslexia and dyscalculia in Mathematics has been attributed to the feeling of tension, helplessness, mental disorganisation, and dread one has when required to manipulates numbers and shapes and solving of scientific and mathematical problems (Ashcraft and Faust, 1994). Norwood (1994) emphasized that dyslexia and dyscalculia did not appear to have a single cause but it was the result 
of many different factors such as truancy, poor self image, poor coping skills, teacher attitudes and emphasis on learning through drill without understanding. However, Greenwood (1984) stated that the principal cause of dyslexia and dyscalculia has been in teaching methodologies. The problems dyslexia and dyscalculia could be minimized if teachers apply the problem solving process to the teaching of sciences and mathematics (Greenwood, 1984).

Many students found learning sciences and mathematics boring, meaningless, and unn-involving (Mitchell, 1993). Lack of motivation and other cognitive variables helps to explain the low level of students' competence in science subjects like Physics and Chemistry. A report on the future of science education (National Research Council, 1989), stated that when mathematics acts as a filter, it does not only filters students out of careers in sciences, but frequently out of school itself. Since mathematics is the core of sciences. Lack of confidence when working in mathematical situations is described by Stuart (2000) as the cause of dyslexia and dyscalculia.

Tobias (1978) believed that word problems are the heart of science subjects. Learners need higher levels of reasoning to solve sciences and mathematics problems, otherwise learners may grow up avoiding mathematics and sciences. Tobia, (1978). Newstead (1998) found that when students were asked to perform and provide explanations in front of teacher or peers, constructive arguments by the peers and careful guidance by their teacher of sciences help to minimize ambiguity that could cause dyslexia and dyscalculia. Kogelman (1982) submitted that experience of learners when punished or humiliated in class was very damaging. Newstead (1998) concluded that learners learn how to do sciences and mathematics before they are able to explain problems and communicate it proficiently.

Dyslexia and Dyscalculia is quite varied both in symptoms and causes. Dyslexia causes children to struggle with reading Often the symptoms when encountering mathematics anxiety are physiological such as sweaty palms, nausea, heart palpations, a hot tingling feelings, stomach aches or stomach cramps and tightening muscles (Clawson, 1991; Godbeg, 1997; Perry, 2004).

Sometimes the symptoms are psychological, such as paralysis of thought, extreme nervousness, inability to hear the teacher, tendency to become upset by noises, inability to concentrate or loss of concentration, preoccupation with intrusive thoughts and worries, and a general sense of uneasiness (Ashcraft \& Kirk, 2001; Godbeg, 1997; Perry, 2004).

The causes of dyscalculia are varied. "Anxious students have difficulty in learning mathematics in the first place, difficulty in using or transferring knowledge from one concept to another, and difficulty demonstrating their knowledge on tests" (Slavin, 2003). Some causes "includes under-preparedness, abscesses from school, parents perpetuating the myth that mathematics ability is hereditary, and negative past experiences with teachers" (Godbeg, 1997). Dyscalculia has been related to personality type, a negative attitude towards mathematics, mathematics avoidance, mathematics background, instructor's behaviour, level of mathematics involvement, lack of confidence, and negative school experiences (Bursal \& Paznokas,2006).
A number of factors have been described as the causes of dyslexia and dyscalculia. Norwood (1994) described dyslexia as the inability to handle frustration, excessive school absences, poor self-concept, parental and teacher attitudes towards mathematics and emphasis on learning mathematics through drill without understanding. Lack of confidence when working in mathematical situations has been described by Stuart (2000) as the cause of mathematics anxiety. Hodges (1993) argues that failure or success in mathematics may be related to individual learning styles and more specifically with the coupling of learning styles and the way in which material is presented.

\section{Effects of Dyslexia and Dyscalculia on Students}

Dyslexia and dyscalculia often compounded over time and can affect students in a variety of ways. Dyslexia and dyscalculia can begin at any age of schooling even as young as elementary school, but most students commonly have negative experiences between seventh and tenth grades (Clawson, 1991). Unless addressed directly, this anxiety often continues or even worsens through high school, college and adulthood.

Dyslexia and dyscalculia is not only difficult for the students to deal with, but it compounded into lack of understanding of major concepts. This can close doors for students in their chosen careers if they are studying mathematics either directly, or indirectly. Lack of understanding of basic mathematical principles can be attributed to inability to solve chemistry, engineering, and other scientific problems (Bursal \& Paznokas, 2006). It also prevents students from acquiring logic and reasoning skills that can be used in variety of areas, even outside the realm of mathematics (Paznokas, 2006).

\section{Methodology}

The design of the study is descriptive research design. This is because, it describes systematically the behaviour and characteristics of a given population or area of interest factually and accurately. Also, the design is considered appropriate for this study because the study does not involve manipulation of variables. The population of the study consist of all students of senior secondary school (SS1) of both public and private secondary school in AdoEkiti Metropolis in Nigeria. Simple random sampling technique was used to select the subject. The sample of the study consisted of two hundred (200) students who were randomly selected from four different schools, two of which are public secondary schools, while the other two were private secondary schools. The instruments used for this study was a questionnaire. The questionnaire was divided into two sections; section A contains items designed to elicit personal data of the respondents such as sex, age, class and departments. Section B, contains items on the effects of anxiety on the teaching and learning of mathematics among secondary school students. The instrument was presented to the researcher's supervisor for critical examination and verification in order to ensure the face and content validity of the instrument. The instrument was thoroughly examined and the corrections 
and suggestion made by the supervisor was used to prepare the final copy of the instrument for administration. The research instrument was administered by the researchers with the help of class teachers.

\section{Research Questions}

This study sought to provide answers to the following research questions

1. Does positive self-esteem lead to a significant reduction in dyslexia and dyscalculia?

2. How can the application of different teaching method combined with the use of teaching aids gives room for self expression and a reduction in dyslexia and dyscalculia?

3. Did dyslexia and dyscalculia have any significant effects on students' poor performance in mathematics?

4. How can effective communication between the teacher and the students' leads to a reduction in dyslexia and dyscalculia among secondary school students'?

5. Did emotional disturbance have any significant effect on students' thinking ability and an increase in dyslexia and dyscalculia?

Research question 1: Does positive self-esteem lead to a significant reduction in dyslexia and dyscalculia?

Table 1. Contigency table for the expected frequency

\begin{tabular}{|c|l|l|l|l|l|l|}
\hline & \multicolumn{1}{|c|}{ SA } & A & D & SD & TOTAL \\
\hline 1 & $\begin{array}{l}\text { Low Self esteem causes } \\
\text { dyscalculia and dyslexia }\end{array}$ & 173 & 224 & 277 & 326 & 1000 \\
\hline 2 & $\begin{array}{l}\text { dyscalculia and dyslexia } \\
\text { affects Learning styles }\end{array}$ & 435 & 303 & 138 & 124 & 1000 \\
\hline 3 & $\begin{array}{l}\text { Degree of performance in } \\
\text { mathematics could be } \\
\text { measure through dyscalculia } \\
\text { syndrome }\end{array}$ & 265 & 298 & 174 & 263 & 1000 \\
\hline 4 & $\begin{array}{l}\text { Teachers students } \\
\text { relationship catalysis } \\
\text { dyscalculia and dyslexia }\end{array}$ & 318 & 249 & 142 & 291 & 1000 \\
\hline 5 & $\begin{array}{l}\text { Emotional intelligence could } \\
\text { be identified through } \\
\text { dyscalculia and dyslexia }\end{array}$ & 325 & 321 & 199 & 155 & 1000 \\
\hline
\end{tabular}

Table 2. Positive self-esteem lead to a significant reduction in dyscalculia and dyslexia

\begin{tabular}{|c|c|c|c|c|c|}
\hline & $\mathrm{O}$ & $\mathrm{E}$ & $(\mathrm{O}-\mathrm{E})$ & $(\mathrm{O}-\mathrm{E})^{2}$ & $(\mathrm{O}-\mathrm{E})^{2} / \mathrm{E}$ \\
\hline SA & 35 & 50 & -15 & 225 & 4.5 \\
\hline A & 45 & 50 & -5 & 25 & 0.5 \\
\hline D & 55 & 50 & 5 & 25 & 0.5 \\
\hline SD & 65 & 50 & 15 & 225 & 4.5 \\
\hline TOTAL & 200 & 200 & & $\chi 2$ & 10 \\
\hline
\end{tabular}

At $\alpha$ level of 0.05 , the chi-square tabulated value for 3df is 7.83. since the calculated value (which is 10) is greater than the chi-square tabulated value, it shows clearly that positive self-esteem lead to a significant reduction in dyscalculia and dyslexia.

Research question 2: How can the application of different teaching method combined with the use of teaching aids gives room for self expression and a reduction in dyslexia and dyscalculia?
Table 3. Chi-square table for learning style and dyslexia and dyscalculia

\begin{tabular}{|c|c|c|c|c|c|}
\hline & $\mathrm{O}$ & $\mathrm{E}$ & $(\mathrm{O}-\mathrm{E})$ & $(\mathrm{O}-\mathrm{E})^{2}$ & $(\mathrm{O}-\mathrm{E})^{2} / \mathrm{E}$ \\
\hline $\mathrm{SA}$ & 87 & 50 & 37 & 1369 & 27.38 \\
\hline $\mathrm{A}$ & 61 & 50 & 11 & 121 & 2.42 \\
\hline $\mathrm{D}$ & 28 & 50 & -22 & 501.8 & 10.04 \\
\hline SD & 25 & 50 & -25 & 635 & 12.7 \\
\hline TOTAL & 200 & 200 & & $\chi 2$ & 52.54 \\
\hline
\end{tabular}

$\mathrm{Df}=(\mathrm{n}-1)=4-1=3$

At $\alpha$ level of 0.05 , the chi-square tabulated value for 3df is 7.83. Since the calculated value is greater than the chi-square tabulated value, therefore effective learning styles, through the application of different teaching methods, with the use of teaching aids turns mathematics concepts from abstract to real situation, which eventually give rooms for self-expression, which leads to low level of dyslexia and dyscalculia.

Research Question 3: Did dyslexia and dyscalculia have any significant effects on students' poor performance in mathematics?

Table 4. chi-square table for students' performance in mathematics

\begin{tabular}{|c|c|c|c|c|c|}
\hline & $\mathrm{O}$ & $\mathrm{E}$ & $(\mathrm{O}-\mathrm{E})$ & $(\mathrm{O}-\mathrm{E})^{2}$ & $(\mathrm{O}-\mathrm{E})^{2} / \mathrm{E}$ \\
\hline SA & 53 & 50 & 3 & 9 & 0.18 \\
\hline A & 60 & 50 & 10 & 100 & 2 \\
\hline D & 35 & 50 & -15 & 225 & 4.5 \\
\hline SD & 52 & 50 & 2 & 4 & 0.08 \\
\hline TOTAL & 200 & 200 & & $\chi 2$ & 6.76 \\
\hline
\end{tabular}

$\mathrm{Df}=(\mathrm{n}-1)=4-1=3$

At $\alpha$ level of 0.05 , the chi-square tabulated value for 3df is 7.83. From Table 3, it is clear that the calculated value is less than the chi-square tabulated value; it therefore indicates clearly that poor performance lead to lack of interest and discouragement in mathematics, which eventually increases tension.

Effective communication between the teacher and the students with a reduction in the use of punitive measure such as open disgrace, insults, raining of abusive words and the use of cane when a student miss a concept in mathematics class lead to a reduction in mathematics anxiety.

Research Question 4: How can effective communication between the teacher and the students' leads to a reduction in dyslexia and dyscalculia among secondary school students'?

Table 5. Chi-square table for teachers - students' relationship

\begin{tabular}{|c|c|c|c|c|c|}
\hline & $\mathrm{O}$ & $\mathrm{E}$ & $(\mathrm{O}-\mathrm{E})$ & $(\mathrm{O}-\mathrm{E})^{2}$ & $(\mathrm{O}-\mathrm{E})^{2} / \mathrm{E}$ \\
\hline $\mathrm{SA}$ & 64 & 50 & 14 & 196 & 3.92 \\
\hline A & 50 & 50 & 0 & 0 & 0 \\
\hline D & 28 & 50 & -22 & 484 & 9.68 \\
\hline SD & 58 & 50 & 8 & 64 & 1.28 \\
\hline
\end{tabular}

$\mathrm{Df}=(\mathrm{n}-1)=4-1=3$

At $\alpha$ level of 0.05 , the chi-square tabulated value for 3df is 7.83. Since the calculated value (14.88) is greater than the chi-square tabulated value, therefore positive attitudinal disposition of teacher towards the students whenever they miss a concept in mathematics class rather than punitive measure such as curses, open disgrace, insults, raining of abusive words and the use of cane lead 
to freedom of expression, which stimulate the students to try more. This eventually leads to a reduction in the level of fear, apprehension, tension and mathematics anxiety.

Research Question 5 Did emotional disturbance have any significant effect on students' thinking ability and an increase in dyslexia and dyscalculia?

Table 6. Chi-square table for emotional intelligence and mathematics anxiety

\begin{tabular}{|c|c|c|c|c|c|}
\hline & $\mathrm{O}$ & $\mathrm{E}$ & $(\mathrm{O}-\mathrm{E})$ & $(\mathrm{O}-\mathrm{E})^{2}$ & $(\mathrm{O}-\mathrm{E})^{2} / \mathrm{E}$ \\
\hline SA & 65 & 50 & 15 & 225 & 4.5 \\
\hline A & 64 & 50 & 14 & 196 & 3.92 \\
\hline D & 40 & 50 & -10 & 100 & 2 \\
\hline SD & 31 & 50 & -19 & 361 & 7.22 \\
\hline TOTAL & 200 & 200 & & $\chi 2$ & 17.64 \\
\hline
\end{tabular}

At $\alpha$ level of 0.05 , the chi-square tabulated value for 3df is 7.83. Since the calculated value is greater than the chi-square tabulated value, it shows that emotional disturbance such as frustration, worried, fear etc increases the level of mathematics anxiety.

\section{Discussion}

The analysed data revealed a lot of factors which leads to a high level of mathematics anxiety among secondary school students. From the results gathered, it was observed that negative self-esteem leads to a high level of mathematics anxiety. The findings revealed that selfcondemnation lead to self-defeat, poor performance and failure in mathematics.

The results revealed that understanding mathematics concept instead of cramming the solution through the application of different teaching methods leads to a reduction in the level of mathematics anxiety. It shows the important role of teaching aids on learning process because it transform the concepts from abstract to real situation which stimulate the students interest.

The findings show that the degree of performance in mathematics and mathematics anxiety are related. Poor performance lead to lack of interest which subsequently lead to high level of mathematics anxiety. This agreed with the views of Ma and Xu,(2004), Norwood, (1994), Reynolds (2000) , Salako and Amato (1995) that low grade or failure in mathematics could also led to mathematics anxiety or increased existing levels of anxiety for mathematics.

The result also revealed that students -teachers relationship has a significant level on mathematics anxiety among secondary school students. It show that positive attitudinal dispositions of the teacher towards the students whenever they miss a concept in mathematics class rather than punitive measure such as curses, open disgrace, insults, raining of abusive words and the use of cane lead to freedom of expression, which encourage the students to try more. This also depicts the view of Kogelman (1982) that experience of learners when punished or humiliated in mathematics class was very damaging. It also agreed with the views of Pianta and Walsch, (1996), Rutter (1997) that teachers student relationship impact positively on students, developing a sense of self and promoting resiliency in them.
The result also shows that emotional intelligence such as emotional disturbance, frustration, worried, fear increases the level of mathematics anxiety. These results agreed with the views of Ashcraft and Faust (1994) that highly anxious mathematics individuals will be less fluent in computation, less knowledgeable about mathematics and less likely to have discovered special strategies and relationship within the mathematics domains.

\section{Conclusion}

Based on the results of the study, the following conclusions are drawn. Self judgment and determination goes a long way in the learning outcomes of students. If the students view themselves positively, believing that they have the ability and the potential to perform excellently well in mathematics, this will inject some strength and interest in them. Hence, positive learning outcomes in mathematics are likely to be obtained.

Self condemnation on the other hand destroy the students confidence and lower there morals. These accelerate the rate of fear, tension and anxiety which leads to poor learning outcomes in mathematics.

Teacher's method of presenting behavioural objectives goes a long way in determining the performance of the students. The method used by the teacher either boost the students morale in mathematics or discourage them, depending on the knowledge of the subject matter, preparation on the part of the teacher, presentation and the nature of the teaching aid employed in the process.

Poor performance weakens the morale of the students which results to lack of interest. Poor performance was caused by series of mistakes and mistakes on the other hand was a result of fear, uneasiness, tension and frustration. All these lead to high level of mathematics anxiety.

Positive teacher's students relationship increases the level of freedom of the students or increases their level of closeness and interaction with the teacher. This closeness encourages the students to ask questions and express their opinion because the assurance is there that even if they miss it the teacher will definitely correct their mistakes. This positive relationship encourages the students to try more problems, which leads to a reduction in the level of mathematics anxiety.

Emotional disturbance during mathematics class leads to less frequent in mathematical computation and manipulation of numbers and more mistakes. However, this result in poor performance in mathematics which results in discouragement and finally high level of mathematics anxiety.

\section{Recommendations}

Based on the findings of this study, the following recommendations were made:

One-on-one instruction is essential for all children especially those with learning difficulties. Create a set study time after school when you'll be available to help your student with homework.

Students should belief in themselves and try to exhibit positive self-judgement. If the students belief that they can, it will increase their strength, encourage them to try several problems and their intelligence ability will be open 
up to receive new concepts. Teachers should not relent on their effort in finding the best method that will bring the best performance out of the students. The importance of teaching aids should not be undermined. Right/wrong answers should be discouraged; rather, emphasis should be laid on steps taking while marking mathematics exercise so as to reduce poor performance to the barest minimum. Continuous assessment should also be encouraged and various techniques should be adopted in conducting the continuous assessment. Various method such as project work, take home assignment, open book test etc. Should be employed so as to reduce failure to the barest minimum. Students should try to avoid situation that can create emotional imbalance. In case of an inevitable situation, students should relax by playing games, watching films or listening to music to ease their tension before coming back to solve mathematics problems. Finally, teachers should try to bear the issues of individual difference while attending to his students. $\mathrm{He}$ /she should try to counsel their students whenever they notice something strange like fear, worrying, frustration or any sort of emotional disturbance in their students that can hinder absolute concentration.

\section{References}

[1] Adler, M. (1985): How to speak, how to listen. New York: MacMillan Publishing company.

[2] Ahmad Shukri Yahaya, Hafsah Abdul Majid \& Muriati Mukhtar (1996). Kegelisahan matematik di kalangan pelajar kejuruteraaan, Kampus Cawangan Perak. Prosiding Simposium Kebangsaan Sains Matematik ke VII. [Mathematics anxiety among engineering university students, Perak Branch Campus. Proceedings of the National Mathematical Science Simposium VII]. Perak:USM.

[3] Aiken, L. R. (1991): A meta-analysis of the relationship between anxiety achieivement in mathematics. Journal for research in mathematics education. Vol. 30 No. 5.

[4] Akinsola, M. K. (2008): Relationship of some psychological variables in predicting problem solving ability of in-service mathematics teacher. The Montana.

[5] Allport, G. W (1935): Attitudes. In C. A. Murchinson (Ed). A handbook of social psychology. Worcester, mass: Clark University press.

[6] Ashcraft, M.H. (2002). Math anxiety: Personal, educational, and cognitive consequences.Directions in Psychological Science, 11, 181-185.

[7] Ashcraft, M. H., \& Kirk, E. P. (2001). The relationships among working memory, math anxiety, and performance. Journal of Experimental Psychology: General, 130(2), 224-237.

[8] Ashcraft, M. H., \& Faust, M. W. (1994). Mathematics anxiety and mental arithmetic performance: An exploratory investigation. Cognition and Emotion, 8, 97-125.

[9] Baloglu, M. (2001): An application of structural equation modelling techniques in the prediction of statistics anxiety among college students. Unpublished doctoral dissertation, Texas A \& M. University.

[10] Baloglu, M, \& Kocak, R (2006): A multivariate investigation of the differences in mathematics anxiety. Pers. Individ. Differ. 40(7): 1325-1335.

[11] Bandura, A (1986): Social foundations of though and action: A social cognitive theory. Englewood cliff. NJ: Prentice Hall.

[12] Bar-on's, R. (1997): Bar-on emotional quotient inventory: A measure of emotional intelligence. Toronto, Canada: Multi-Health system.

[13] Baron-on, (2006): The Bar-on model of emotional social intelligence (ESI). Psicothema, 18 supl, 13-25.

[14] Benner, A.D, Mistry, R.S. (2007). Congruence of mother and teacher educational expectations and low-income youth's academic competence. Journal of Educational Psychology, 99 (1). 140-153.
[15] Betz, N. E. (1978). Prevalence, distribution and correlates of math anxiety in college students. Journal of Counseling Psychology, 25, 441-448.

[16] Blair, C., GMAON, D,. Thorne, S., Baker., D, (2005): Rising mean IQ. Cognitive demand of mathematics education for your children population exposure to formal schooling and the neurobiology of the preferential cortex. Intelligence. 33: 93-106.

[17] Bretscher, A.S., Dwinell, P.L., Hey, N.S \& Higbee, J.L. (1989). Success or failure: Variables affecting mathematics performance. Paper presented at the National Association of Developmental Education, Cincinnati, OH. (ERIC Document Reproduction Service No: ED 304340).

[18] Bursal, M. \& Paznokas, L. (2006). Mathematics anxiety and preservice elementary teachers' confidence to teach mathematics and science. School Science and Mathematics, 106(4), 173-180. Retrieved June 22, 2006, from EBSCO database.

[19] Butterworth, B. (1999). The mathematical brain. London: Macmillan.

[20] Cartwright, S. And Pappas, C. (2008): Emotional intelligence, its measurement and implications for the work place. International journal of management review 10(2) 149-171.

[21] Carr, M (1990): The role of context and development from a life span perspective. In $\mathrm{W}$ Schneider and F. E Weinert (eds). Interactions among aptitudes, strategies, and knowledge in cognitive performance, New York: springer verlag, 222-231.

[22] Cates, Gary L.a; Rhymer, Katrina N. "Examining the Relationship Between Mathematics Anxiety and Mathematics Performance: An Instructional Hierarchy Perspective", Journal of Behavioral Education Vol: 12, Issue: 1, March 2003 pp. 23-34.

[23] Craven, R. G., Marsh, H.W., \& Debus, R. L. (1991). Effects of internally focused feedback and attributional feedback on enhancement of academic self-concept. Journal of Educational Psychology, 83(1). 17-27.

[24] D’Ailly, H. \& Bergering, A. J. (1992). Mathematics anxiety and mathematics avoidance behaviour: a validation study of two factor Educational and Psychological Measurement, 52(2), 369-378. Retrieved April 10, 1999, from EBSCO database.

[25] Daskalogianni, K \& Simpson, A. (2000): Towards a definition of attitude: The relationship between the effective and the cognitive in pre-university students. Proceedings of PME 24, vol.2, 217-224, Hiroshima, Japan.

[26] Enwisle, O. \& Hayduk, L. (1988): Lasting effects of elementary school. Sociology of education, 61, 147-159.

[27] Evans, J, Floyd, R, McGrwe K. S, Leforgee, M. (2002): The relation between measures of cattel-Horne-carroll (CHC) cognitive ability and reading achievement during childhood and adolescents.

[28] Fergusan, R. F. (1991): Paying for public education. New evidence on how and why money matters. Harvard Journal of Logislation 28(2), 465-495.

[29] Fishbein, M \& Ajzen, I (1975): Belief, attitude, intention and behaviour. An introduction to theory and research. Reading, mass: Addison-Wesley.

[30] Fox, M. (1993): Psychological perspective in education: London: Cassel Educational Ltd.

[31] Furner, Joseph M., Berman, Barbara T., "Math anxiety: Overcoming a major obstacle to the improvement of student math performance", Childhood Education, Spring 2003.

[32] Gardner, H. (1983): Frames of mind. New York: Basic books.

[33] Gentile, J. R. \& Monaco, N. M ,(1986): Learned helplessness in mathematics. What educators should know. Journal of mathematical behaviour, 5(2): 159-178.

[34] Goleman, D (1996): Emotional Intelligence; London: Bloomsbury.

[35] Godbey, C. (1997): Mathematics Anxiety and the underprepared students classroom teacher guide.

[36] Goldstein, L \& Lake, U. (2000): "Love, love and more love for children”. Exploring preservice teachers’ understanding of caring. Teaching and teacher education, 16(8), 861-872.

[37] Good, T. L \& Brophy, J. E. (2000): Looking in classroom (8th ed). New York. Longman.

[38] Goulding, M., Rowland, T., Barber, T. (2002). Does it matter? Primary teachers trainees' subject knowledge in mathematics. British Educational Research Journal, 28, 689-704.

[39] Gierl, M., \& Bisanz, J. (1995). Anxieties and attitudes related to mathematics in grades 3 and 6.The Journal of Experimental Education, 63(2), 139-58. 
[40] Hardfield, O.D., Martin, J.V., \& Wooden, S.(1992). Mathematics anxiety and learning style of Navajo Middle School student. School Science and Mathematics, 92(4), 21-176.

[41] Hembree, R. (1990). The nature, effects, and relief of mathematics anxiety. Journal for Research in Mathematics Education, 21, 33-46.

[42] Honey, P \& Mumford, A (2006). The Learning Styles Questionnaire, 80-item version. Maidenhead, UK, Peter Honey Publications.

[43] Hopko, Derek R.; McNeil, Daniel W.; Lejuez, C.W.; Ashcraft, Mark H.; Eifert, Georg H.; Riel, Jim "The effects of anxious responding on mental arithmetic and lexical decision task performance" Journal of Anxiety Disorders Vol: 17, Issue: 6, 2003 pp. 647-665.

[44] Jasmani Bidin, Noorzila, S. \& Kasim, Z. (2005). Kegelisahan matematik di kalangan pelajar menengah rendah di Perlis. Prosiding Simposium Kebangsaan Sains Matematik keXIII. [Mathematics anxiety among lower secondary school students in Perlis. Proceedings of the National Mathematical Science Simposium XIII].

[45] Kass, Michael (1994). "Michael Kass's notes on the humanistic theories of psychology as told by Kevin Travis(bonus pts.)"

[46] Kulm, G. (1980). Research on mathematics attitude. In R. J. Shumway (Ed.), Researchin mathematics education (pp. 356-387). Reston, VA, NCTM.

[47] Leflot, G., Onghena, P., \& Colpin, H. (2010). Teacher-Child Interactions: Relations with children's self-concept in second grade. Infant and Child Development, 19(4).385-405.

[48] Laturner, R.J. (2002) Teachers' academic preparation and commitment to teach math and science. Teaching and Teacher Education, 18, 653-663.

[49] Marsh. H.W. \& Martin, A.J. (2011). Academic self-concept and academic achievement: Relation and causal ordering. British Journal of Educational Psychology, 81. 59-77.

[50] Ma,X.(1999) A meta-analysis of the relationship between anxiety toward mathematics and achievement in Mathematics Journal for Research in mathematics Education,30(5),520-540.

[51] Ma, X. (2003). Effects of early acceleration of students in mathematics on attitudes toward mathematics and mathematics anxiety. Teachers College Record, 105(3), 438-464.

[52] Ma, X. \& Xu, J. (2004). The causal ordering of mathematics anxiety and mathematics achievement: a longitudinal panel analysis. Journal of Adolescence, 27(2), 165-179. Retrieved April 20, 2004, from Science Direct database.

[53] McLeod, D. B. (1989). Beliefs, attitudes, and emotions: New views of affect in athematics education. In D. B. McLeod and V. M. Adams (Eds.), Affect and athematical problem solving: A new perspective (pp. 245-258). New York: pringer-Verlag.

[54] Miller, L. D. \& Mitchell, C. E. (1994). Mathematics anxiety and alternative methods of evaluation. Journal Of Instructional Psychology, 21(4), 353-359. Retrieved April 9, 1999, from EBSCO database.

[55] National Research Council. (1989). Everybody counts: A report to the nation on the future of mathematics education. Washington, DC: National Academy Press.

[56] Norwood, K. S. (1994). The effect of instructional approach on mathematics anxiety and achievement. School Science And Mathematics, 94(5), 248-254. Retrieved April 25, 1999, from EBSCO database.

[57] Perry, A. B. (2004). Decreasing mathematics anxiety in college students. College Student Journal, 38(2), 321. Retrieved June 29, 2006, from EBSCO database.

[58] Preckel, F., \& Brull, M. (2010). The benefits of being a big fish in a big pond: Contrast and assimilation effects on academic selfconcept. Learning and Individual Differences, 20(5). 522-531.

[59] Quilter, D. \& Harper, E. (1988). Why we didn't like mathematics, and why we can't do it. Educational research, 30, 121-134.

[60] Reglin, G. L. (1990). The effects of individualized and cooperative computer assisted instruction on mathematics achievement and mathematics anxiety for prospective teachers. Journal Of Research On Computing In Education, 22(2), 404-414. Retrieved February 2, 1999, from EBSCO database.

[61] Reynolds, M. (2001). The relationship between mathematics anxiety and motivation: a path analysis.Retrieved October 02, 2002, from http://tigersystem.net/area2002/viewproposaltext.asp?propID=278 6.
[62] Richardson, F. C., \& Suinn, R. M. (1972). The Mathematics Anxiety Rating Scale: Psychometric data. Journal of Counseling Psychology, 19, 551-554.

[63] Richardson, F. C., \& Woolfolk, R. L. (1980). Mathematics anxiety. In I. G. Sarason (Ed.), Testanxiety: Theory, research and application (pp. 271-288). Hillsdale, NJ: Erlbaum.

[64] Royster, D. C, Haris, M. K, \& Schoeps, N. (1999): Disposition of College Mathematics students. International Journal of Mathematics Education in Science and Technology, 30(3), 317333.

[65] Satake, E. \& Amato, P. (1995). Mathematics anxiety and achievement among Japanese Elementary School students. Educational And Psychological Measurement, 55(6), 1000-1008. Retrieved June 6, 2002, from EBSCO database.

[66] Saha, S. (2007): A study of gender attitudes to mathematics, Cognitive style and achievement in mathematics. Exper. Educ. 35:61-67.

[67] Sava, F. A (2001): Causes and effects of teacher conflict-inducing attitudes towards pupils: A path analysis model. Journal of teaching and teacher education, 18, 1007-1021.

[68] Slater, L. (2004): Relationship-Driven teaching cultivates collaboration and inclusion. Kappa Delta Pi Record 40(2), 58-59.

[69] Slavin, R. E. (2003): Educational Psychology. Boston: Allyn and Bacon. Students as related to achievement, gender and age. Inquirey, 9(1). Students journal of educational psychology, 80(2), 210-216.

[70] Stuart, v. (2000): Math Curse or Math Anxiety? Teaching children mathematics, 6(5): 330-335.

[71] Smeyer, A., Dickstein, S., Seifer, R., Guisti, L, Magee, K \& Spritz B. (2001): Emotional competence and early school adjustment: A study of pre-schoolar at Risk. Early educational and development, 12(1), 73-76.

[72] Tapia, M. (2004). The relationship of math anxiety and gender. Academic Exchange Quarterly, 8 (2).

[73] Thomas, H. \& Furner, J. M. (1997). Helping high ability students overcome mathematics anxiety through bibliotherapy. Journal Of Secondary Gifted Education, 8(4), 164-179.

[74] Tiedemann, J. (2000). Parents' gender stereotypes and teachers' beliefs as predictors of children's concept of their mathematical ability in elementary school. Journal of Educational Psychology, 92(1), 144-144-151.

[75] Tobias, S. (1978): Overcoming Maths Anxiety, Norton, New York

[76] Townsend, M. A. R., Moore, D. W., Tuck, B. F. \& Wilton, K. M. (1998). Self concept and anxiety in university students studying social science statistics within a co-operative learning structure. Educational Pschology, 18(1), 41-55.

[77] Trautwein, U., Ludtke, O., Nagy, G., Marsh, H.W. (2009). WithinSchool Social Comparisons: How students perceive the standing of their class predicts academic self-concept. Journal of Educational Psychology, 101 (4). 853-866.

[78] Umay, A. (1996). Matematik egitimi ve olculmesi (Mathematics education and measurement of mathematics). Hacettepe Universitesi, Egitim Fakultesi Dergisi, 12, 145-149.

[79] Uusimaki, L. \& Nason, R. (2004). Causes underlying pre-service teachers' negative beliefs and anxieties about mathematics. Proceedings of the 28 th Conference of the International Group for the Psychology of Mathematics Education, 4, 369-376.

[80] Vann, B. D. N. (1993). Mathematics anxiety: parental anxiety as it relates to anxiety in children. Proquest Dissertations and Theses, 53(08) DAI-A. (Publication No. AAT 9237315)

[81] Williams, J. (1994). Anxiety measurement construct validity and test performance. Measurement And Evaluation in Counseling and Development, 27(1), 302-308. Retrieved April 25, 1999, from EBSCO database

[82] Woodard, T. (2004). The effects of mathematics anxiety on postsecondary developmental students as related to achievement, gender, and age. Inquiry, 9(1). Retrieved June 29, 2006, from http://www.vccaedu.org/inquiry/ inquiry-spring2004/i-91woodard.html.

[83] Woolfork, A. E. (1995): Educational Psychilogy (6th Ed.). Allyn and Bacon. Retrieved from http:wik.ed.uuc.edu index.php?title=math anxiety \& oldid=45789.

[84] Yüksel-Şahin, F. (2004). Orta ogretim ogrencilerinin ve universite ogrencilerinin matematik korku düzeyleri (Levels of the mathematics worry of high school students and university students). Egitim Bilimleri ve Uygulama Dergisi, 3(5), 57-74. 